\title{
Kalite Fonksiyon Göçerimi ve Homojenize Yoğurt Üretiminde Uygulaması
}

\author{
Quality Function Deployment and Application Essay in Homogenized Youghurt Production
}

Mehmet Selami YILDIZ1 , Züleyhan BARAN²

\begin{abstract}
ÖZET
Rekabetin küresel boyut kazandığı günümüzde işletmelerin ürün geliştirme ve müşterilerin taleplerine hızlı cevap verebilme yetenekleri, başarıı ılabilmeleri açısından önemlidir. Kalite Fonksiyon Göçerimi (KFG), firmaların ürün tasarım süreçlerinde müşteri ihtiyaç ve beklentilerini karşılamaya yönelik olarak uyguladıkları bir yaklaşımdır. KFG müşteri beklentilerine uygun ürünlerin geliştirilme süresini kısaltarak firmalara sektörde rekabet üstünlüğü sağlar. Bu araştırmanın amacı, süt ürünleri endüstrisinde KFG yaklaşımının oluşturulması ve uygulanabilirliğini araştırmaktır. Bu kapsamda, süt ürünleri üretimi yapan bir firmada, müşteri beklentilerini karşılamak ve firmanın sektördeki rekabet gücünü arttırmak amacıyla homojenize yoğurt ürünü için KFG uygulaması gerçekleştirilmiştir. Araştırma bu yönüyle KFG'nin endüstriyel düzeyde uygulama alanını genişleterek literatüre ve uygulamaya katkı yapmaktadır. Uygulama sonucunda firmaya homojenize yoğurt ürünü için müşteri tatminini arttıracak ve rekabet avantajı sağlanabilecek bir takım önerilerde bulunulmuştur. Ayrıca KFG yaklaşımının, gıda sektöründe benimsenmesi halinde mevcut ürünlerin müşteri talepleri doğrultusunda iyileştirilmesi yönünde, özellikle hızlı cevap verme konusunda belirleyici bir öneme sahip olduğu anlaşılmıştır.
\end{abstract}

Anahtar Kelimeler: Kalite, kalite fonksiyon göçerimi, ürün geliştirme, homojenize yoğurt

\section{GíRiş}

Globalleşme sürecinde devamlı gelişen dünyamızda işletmelerin piyasadaki varlıklarını sürdürebilmeleri, artan bilinçli tüketici ihtiyaçlarını sürekli takip etmeleri ve bunlara hızlı cevap vermeleri ile mümkündür. Müşteri gereksinimlerinin en kısa zamanda, en az maliyetle ve istenen kalitede sağlanması gibi kriterler süreklilik arz etmelidir. Bu nedenle işletmeler, müşterilerine ulaşmanın yollarını aramalıdırlar. Bu anlamıyla müşterinin dinlenmesi, anlaşılması ve müşterinin söylediklerinin teknik karakteristiklere dönüştürülmesi ve yorumlanması Kalite Fonksiyon Göçerimi (KFG) felsefesini biçimlendirir. KFG, müşterinin sesini mühendislik, üretim ve Ar-Ge kararları ile ilişkilendirmekte, bu fonksiyonlar arasındaki iletişimi geliştirmekte ve işletmeyi başarılı ürün ve süreç uygulamalarına ulaştırmak-

\begin{abstract}
On nowadays competition has reached global dimensions, so companies must develop to their capabilities about product development of enterprises and customer demand to respond quickly that is very important for successful. Quality Function Deployment (QFD) is an approach that companies use for respond to customer needs and expectations in product design processes. QFD enables to achieve competitive advantage to firms in the industry. The purpose of this study, the creation and implementation of QFD approach to investigate in dairy industry. Therefore, QFD application was carried out for homogenized yoghurt products to meet customer expectations and to increase the competitiveness of company in a dairy products industry. In this perspective, this study expand the application fields of QFD approach by extending which has contributed to the literature and practice at the industrial level. As a result of this application, some suggestions were made about homogenized yoghurt products to the company which can be achieved for improving customer satisfaction and competitive advantage. Also adoption of the QFD method is understood to have a decisive importance especially improvement of existing products according to customer requirements for fast response in food industry.
\end{abstract}

Key Words: Quality, quality function deployment, product development, homogenized yoghurt

tadır (Güleş ve Bülbül, 2004).

Günümüzde işletmelerin başarısı; müşteri taleplerini karşılayabilme potansiyeline ve müşteri memnuniyetinin süreklik arz etmesine bağlı olarak artmaktadır. (Abasov, 2002). Bu kapsamda değerlendirildiğinde, işletmelerin başarılı olabilmesinin ve müşteri memnuniyetinin süreklilik arz etmesinin yolu Toplam Kalite Yönetimi, Kalite Güvence Sistemi ve Kalite Fonksiyon Göçerimi uygulamalarının bir bütün olarak uygulanmasından geçmektedir.

Müşterilerin işletmeyi nasıl algıladığı Toplam Kalite Yönetiminin konusudur ve değerlendirme aşamasında büyük ağırlığa sahiptir (Yalçın, 1999). Toplam Kalite Yönetimi (TKY); stratejik ürün planlama, örgütsel planlama, maliyet göçerimi, yazılım geliştirme gibi bir- 
çok alanda kullanılmaktadır (Cohen, 1995). TKY, müşterilerin "kalite" beklentilerini karşılayacak ya da aşacak şekilde iş yapılmasını sağlamak için, bir örgütteki tüm çalışanların katılımı ile iş süreçlerinin sürekli olarak iyileştirilmesini sağlayan bir yönetim felsefesidir (Adrian,1995).

Müşteri istek ve ihtiyaçlarını gözden kaçıran bir sistem, ihtiyaçları zamanında karşılayamayacağından müşteri sadakati ve pazar payının kaybedilmesi sonucuyla karşılaşacaktır. Başarılı işletmeler, müşterilerin mevcut ve gelecek ihtiyaçlarıly birlikte farkında olunmayan yeni ihtiyaç alanlarını belirlemeye de önem verirler. Sektöründe lider işletmelerin en önemli özelliği, müşterilerinin ihtiyaçlarına sürekli olarak cevap verebilen işletmeler olabilmeleridir (Compton, 1999; Prasad vd., 2010).

KFG, müşteri sesini üretime dönüştüren bir metot olmakla birlikte (Sher, 2006, s.292-295) ürün geliştirmeden üretime ve pazarlamadan dağıtıma kadar olan müşteri ihtiyaçlarını ayrıntılı tasarımlara dönüştüren bir süreçtir (Gonzalez vd, 2004, s.335-348). KFG müşteriyi tatmin etmek ve müşterinin taleplerini üretim sırasında kullanılacak başlıca kalite güvence sistemlerine dönüştürmek amacıyla tasarım kalitesini geliştirmeyi amaçlayan ve ürün daha tasarım aşamasındayken güvence altına alan bir sistemdir (Akao, 1990). Günümüzde KFG yaklaşımı firmaların mevcut ürün geliştirme zamanlarını kısaltması, daha iyi kalitede ürün üretilmesini sağlaması ve yüksek müşteri tatminini sağlaması nedeniyle her geçen gün dünya çapında uygulaması artmakta ve daha da büyük öneme sahip olmaktadır (Lee, Wu ve Tzeng, 2008; Deros vd., 2009).

Sosyal ve kültürel gelişimin yansımaları olarak müşterilerin gıda sektöründe üretilen ürünleri sorgulamaları, kaliteli ve güvenli üretim beklentileri büyük ölçüde artmıştır. Bu gelişime paralel olarak müşteri memnuniyetini ve sektörde lider konumda kalabilmek için yaygınlaşan kaliteli ürün sunum çalışmaları, gıda işletmelerinde yapılan üretimlerin kalitesinin tarafsız dış kuruluşlar tarafından belgelendirilmesi düzeyine gelmiştir. Kalite güvence sistemleri olarak adlandırılan bu belgeler, danışmanlık hizmeti veren özel kuruluşlar tarafından belirli bir eğitim programına tabii tutulan ve kurulan bu sistemi işletmelerinde başarıyla uygulayan gıda firmalarına verilmektedir.

Son zamanlarda gıda işletmeleri için popüler olan ISO ve HACCP gıda güvenliği yönetim mevzuatlarını içeren ISO 22000 belgesi için birçok gıda işletmesi danışmanlık hizmeti alarak başvurular yapmaktadır. ISO 22000 bir kılavuz olup, kalite güvence sistemi standartlarını seçerken hangi kriterlere göre seçim yapılması gerektiğini gösteren belgeler bütünüdür. Kalite güvencesi ISO 8402 sözlüğüne göre; "Bir ürün ya da hizmetin, verilen kalite taleplerini karşılayacak, yeterli düzeyde güvenin sağlanması için gerekli planlanmış ve sistematik faaliyetler bütünüdür" (DIN ISO 8402).

Günümüzde gıda sanayisi, her zaman beklentilere cevap verebilen yenilikçi ürünlerin geliştirilmesi konusunda mevcut pazarlar tarafından sürekli bir biçimde zorlanmaktadır. Ürün yaşam süresinin kısalması ve daha çok kalite için artan müşteri talepleri, gıda kalitesinin iyileştirilmesi için planlamaya, yapılandırmaya ve sistematize etmeye yardımcı olabilecek araçlara gereksinim duyulmasına neden olmuştur. Kalite Fonksiyon Göçerimi de müşteriler tarafından talep edilen kaliteyi ürün geliştirme sürecinden yukarıya doğru taşıyarak sağlayan bir araçtır. Bu kapsamda KFG, üretim sürecini kontrol eden ve müşteri memnuniyetine odaklanarak yeni veya iyileştirilmiş ürün veya hizmetlerin pazara daha hızlı bir biçimde girmesine olanak sağlayan bir planlama araçları seti olarak görülebilir (Sofyalıoğlu, 2006)

Rekabet koşullarının zorlaştığı günümüzde tüm bu yaklaşımların uyum içerisinde uygulanması, şüphesiz işletmelerin pazar paylarının yükselmesini ve rekabette üstünlük kazanmalarını sağlayacaktır. KFG yaklaşı$\mathrm{ml}$, yeni ürün geliştirme çalışmaları öncesinde kullanılabileceği gibi, mevcut ürünlerin değerlendirilmesi ve işletmelerin rekabet güçlerini arttırmaları yönünde yöntem geliştirmeleri için de kullanılabilir.

Bu çalışmanın amacı, genel olarak gıda sektöründe özelde ise süt ürünleri işletmelerinde KFG ile kalite evinin oluşturulması ve uygulanabilirliğini araştırmaktır. Ayrıca süt ürünleri üretimi yapan bir firmada, kalite evi uygulaması ile müşteri beklentilerini analiz etmek, müşteri beklentilerini karşılamak ve firmanın sektördeki rekabet gücünü arttırmak amaçlanmaktadır. Yapılan literatür taramasında Gıda Endüstrisinde uygulamaya yönelik KFG çalışmalarının yeterince mevcut olmadığı tespit edilmiştir. Bu kapsamda, daha önce farklı sektörlerde birçok uygulaması yapılan KFG yaklaşımı, gıda sektöründe faaliyet gösteren süt ürünleri işletmelerinde tartışıımış ve kalite evi oluşturulmuştur. Araştırma bu yönüyle KFG'nin gıda sektöründeki uygulama alanını genişleterek literatüre ve uygulamaya katkı yapmaktadır.

\section{KALITE FONKSIYON GÖÇERIMI (KFG)}

KFG, toplam kalite yönetimi içinde müşteri talep ve gereksinimlerinin, örgütün bütün fonksiyonel bileşenlerindeki ürün/hizmet karakteristiklerine dönüştürülmesini sağlayan ve multidisipliner bir sistem tarafından yürütülen, anlaşılması kolay ve müşteri 
memnuniyetini güvence altına almaya yarayan yapısallaşmış bir üretim planlama ve geliştirme yöntemidir (Juran 1992, Zultner 1993, s.79-91, qfdi.org). KFG, nihai ürünün müşteri istek ve ihtiyaçlarını karşılamasını sağlamak için, bu istek ve ihtiyaçların sistemin bütün elemanlarına yayılmasını gerçekleştiren bir prosedürdür (Compton, 1999).

Özellikle ekonomik ve sosyal çevrede çok hızlı bir değişimin yaşandığı, her geçen gün yeni teknolojik buluşların söz konusu olduğu, müşteri beklentilerinin sürekli arttığı günümüzde, işletmeler hayatta kalma ve başarılı olmak için daha fazla mücadele etmelidirler (Akao 1990, Costa vd. 2001, s.306-314, Benner vd.2003, s.327-329).

KFG bir araç değil, işletmenin tüm süreçlerinin etkin olarak kullanımında ve öncelikli konuların ortaya konmasında yardımcı olan bir planlama sürecidir. Müşterilerin düşünceleriyle başlayan bu sürecin en önemli girdisi de yine müşterilerin sesidir. Müşterilerin istek ve gereksinimleri, ürün/hizmetlerin geliştirilmesinde önemli bir güçtür. KFG, bir ekip çalışması sonucunda elde edilen girdiler ve alınan kararlarla yol kateden bir süreçtir. Bu nedenle; söz konusu süreç, işletmelerde ortaya çıkan engellerin birçoğunu ortadan kaldırır ve böylece; pazarlama yönetiminin müşteri ile ilgili bilgilerinin, ürün geliştirme mühendislerinin müşteri gereksinimlerine ilişkin bilgi ihtiyacı ile birleştirilmesine yardımcı olarak; tüm işletme uygulamalarının tek bir amaç doğrultusunda bütünleşmesini sağlar (Moran ve Nakul, 1991).

KFG uygulamasının 3 ana hedefi vardır: (Sack, 2001).

1. Dile getirilmiş ve getirilmemiş müşteri beklentilerinin saptanması

2. Bu ihtiyaçların teknik karakteristiklere dönüştürülmesi

3. Müşteri memnuniyeti odaklı kaliteli üretim ve pazarlamanın sağlanması

KFG yaklaşımının uygulanmasıyla işletmeler bazı avantajlar elde ederler. Bunlar: (Han, 2000; Cohen, 1995):

- Müşterinin gerçek ihtiyaçlarının belirlenmesi

• Ürün tasarım veya geliştirme gereksinimlerinin belirlenmesi

- Yeni ürün geliştirme sürecinin etkin planlanmasının sağlanması

- Süreç stratejilerinin geliştirilmesi

• Üretim sürecinin kontrol edilerek kalite ve güvenirliliğin artmasının sağlanması

- Mevcut ürün özellikleriyle ilgili kayıtlı veri tabanının oluşturulması

\subsection{Kalite Fonksiyon Göçeriminin Aşamala-} rı

Geleneksel yeni ürün yaklaşımlarında yeni ürünün geliştirilme süreci ürünün pazara sunulmasıyla son bulmamaktadır. Ürünü satın alan ve kullanan müşterilerden elde edilen geri bildirimler değerlendirilerek üründe gerekli görülen tasarım değişiklikleri ürünün pazara sunumundan sonra da gerçekleştirilmeye devam etmektedir (Besterfield vd, 1999; Hauser ve Clausing, 1988, s.63-73).

KFG temelli yeni ürün geliştirme süreci ise, geleneksel yaklaşımlardan farklı olarak, işletmenin ilgili tüm departman temsilcilerinin katılımıyla oluşturulmuş multifonksiyonel bir takım tarafından yürütülen bir süreçtir. KFG sisteminin uygulamadaki başarısının önemli bir şartı, süreci oluşturacak faaliyetlerin ayrıntılı olarak planlanması ve tüm sisteme tam bir örgütsel desteğin sağlanmasıdır. Böylece hem tüm sürecin kapsayacağı zaman aralığı belirlenmiş olacak hem de KFG sistemi içinde görev alacak organizasyonun tüm departmanları arasında etkin bir bilgi akışı sağlanmış olacaktır (Grover, 2002). Bir organizasyonda genellikle KFG sistemi dört aşamadan oluşmaktadır (King, 1989; Cohen, 1995, Guinta ve Praizler, 1993; Shillito, 1994).
1- Kalite Evi,
2- Ürün Tasarımı,
3- Süreç Planlama,
4- Üretim Planlama.

\subsubsection{Kalite Evi}

Kalite evi müşteriler için en önemli olan konularda hedeflerin oluşturulmasına ve teknik olarak bunların nasıl başarılacağının belirlenmesine yardımcı olur. Mühendisler için temel verileri kullanılabilir formda özetlemeyi sağlarken, pazarlamacılar için müşterinin sesini temsil eder ve yeni fırsatların görünür olmasını sağlar (Bouchereau ve Rowlands, 2000, s.8-19).

Kalite evi aşamasındaki en önemli noktalardan biri, KFG sisteminin uygulanacağı ürünün seçimidir. Doğru ürünün seçilmesiyle, firma gereksiz zaman kayıplarını engelleyerek amaçlarına tam olarak odaklanabilecektir. Herhangi bir KFG projesinin başlangıç noktası, ölçülemeyen müşteri beklentisini belirlemektir. Hem stratejik hem de faaliyet kararlarını belirlemek için "müşterinin sesi" olarak bilinen müşteri girdisine ihtiyaç duyulmaktadır (Griffin ve Hauser, 1993). Bu beklentiler daha sonra teknik özelliklere dönüştürülür. Kalite evinin aşamaları Şekil 1'de gösterildiği gibi 2 ana bölümden (Korelasyon ve ílişkiler) ve bu bölümlerle bağlantılı 6 alt bölümden oluşmaktadır. Bu bölümler Şekil 1'deki Kalite Evinde gösterilmiştir (Kathiravan vd., 2008): 
Şekil 1: Kalite Evi

\begin{tabular}{|c|c|c|c|}
\hline & & Teknik Gereksinimler & \multirow[b]{2}{*}{$\begin{array}{c}\text { Planlama } \\
\text { Matrisi }\end{array}$} \\
\hline \multirow[t]{3}{*}{$\begin{array}{l}\text { Tüketici } \\
\text { Talepleri }\end{array}$} & \multirow[t]{3}{*}{$\begin{array}{l}\text { Tüketici Önem } \\
\text { Düzeyleri }\end{array}$} & llişkiler & \\
\hline & & Teknik tanımlayıcılar & \\
\hline & & $\begin{array}{l}\text { Gerçek ve Hedef Değerler } \\
\text { (Teknik Kıyaslamalar) }\end{array}$ & \\
\hline
\end{tabular}

Kaynak: Kathiravana N., Devadasanb S.R., Bijumon Michael T. and Goyald S.K. 2008. Total quality function deployment in a rubber processing company: a sample application study Production Planning \& Control, 19: 1, 53 - 66

2.1.1.1. Tüketicilerin talepleri: Müşterilerden elde edilen bilgilerle oluşturulan yapılandırılmış bir gereksinimler listesidir. Bu bölümde bulunan bilgiler müşterinin sesini temsil etmektedir. Ürün tasarımına ilişkin bilgi doğrudan müşterinin kendinden elde edilen bilgiler olabileceği gibi müşterinin ürüne bakışı hakkında dolaylı yollardan elde edilen bilgiler olabilir. Her iki şekilde de toplanan bilgi nicel veya nitel karakterli, sistematik veya rasgele toplanmış olabilir (Besterfield, 1999).

2.1.1.2. Tüketici önem düzeyleri: Müşteri ihtiyaçlarının neler olduğu ve bu ihtiyaçların ne derece önemli olduklarının belirlenmesinde kullanılan matristir. Müşteri talep ve gereksinimlerine ait önem dereceleri karmaşık problemlerinin çözümünde kullanılan, karar verme sürecinde objektif ve sübjektif faktörleri birleştirme olanağı sağlayan güçlü bir karar verme tekniğidir. Önem derecesine göre 1 - 10 arasında puanlama yapılır. Bu puanlama daha sonra ilişki matrisinde kullanilır. (Saaty, 1980).

2.1.1.3. Teknik gereksinimler: Teknik cevaplar mühendisin sesi adıyla da bilinmektedir. Bu teknikle mevcut ürünün teknik karakteristikleri belirlenerek müşteri ihtiyaçlarını karşılamaya yönelik ölçümler oluşturulur (Kathiravan vd., 2008).

2.1.1.4. Korelasyon: Kalite evinin çatısını oluşturan kısımdır. Korelasyon matrisi çok az kullanılan bir bölüm olarak bilinse de tasarım mühendisleri için büyük önem arz etmektedir. Her bir teknik gereksinimin birbirleriyle olan pozitif veya negatif ilişkilerini gösterir. Böylece fiziksel çelişkiler ortadan kalkarak teknik gereksinimlerin belirlenmesi işi kolaylaşacaktır. (Hauser ve Clausing, 1988).

Müşteri isteklerini karşılamak amacıyla belirlenen teknik karakteristikler arasında olumlu ya da olumsuz ilişkiler söz konusu olabilir. Bu etkileşimin görülmesi için çatı ya da korelasyon matrisi kullanılır. Çatı benzeri bu yapımın amacı gerekebilecek inceleme ve gelişmeleri tanımlamaktır (Kuru, 1997). Çatı matrisi teknik karakteristikler ve pozitif-negatif korelasyon arasındaki ilişkiyi belirlemek için yardımcı bir matristir (Casamen vd., 2005). Teknik gereksinimler arasında bir takım ilişkilerin bulunması doğaldır. Bir teknik gereksinimin geliştirilmesi direkt ya da dolaylı olarak başka bir teknik gereksinimin olumlu ya da olumsuz etkilenmesine neden olabilir (Yıldırım, 2002).

KFG matrisi oluşturulduktan sonra sıra bu matrisin analizini yapmaya gelmiştir. KFG matrisinin analizi sırasında dikkat edilmesi gereken bazı önemli noktalar aşağıdaki gibidir (Yıldııım, 2002):

- KFG matrisi analizi yapılırken dikkat edilecek ilk nokta boş satır veya sütunun olmamasıdır. Herhangi bir satır veya sütunun boş bulunması eksik veri demektir.

- Bazı durumlarda KFG matrisini oluştururken ilişki matrisinde mühendislik karakteristiğinin hiçbir müşteri isteğini etkilemediği görülür. Bunun sebebi; bu mühendislik karakteristiğinin gereksiz olması ya da müşteri isteklerinden birinin gözden kaçııılmış olması demektir.

- İlişki ve çatı matrislerinin anlaşıımasının kolay olması için birbirleriyle tamamen ilgisiz olan hücrelere başka bir sembol konulabilir.

- Değerlendirmenin sağlıklı olabilmesi için müşteri istekleri sayısının ve mühendislik karakteristikleri sayısının çok fazla olmaması gerekir.

2.1.1.5. Iliş̧kiler: Teknik karakteristiklerin belirlenmesinden sonra sıra teknik karakteristikler ve müşteri istekleri arasında ilişki kurulmasına gelir. Iliş̧i matrisi, süreç boyunca sayısal sıralama yaparak müşteri tatmini için rehber olarak hizmet eder (Özdil ve Dönmez, 2002: 178). Ilişki matrisi teknik karakteristikler (nasıllar) ve müşteri gereksinimleri (neler) arasındaki ilişkinin derecesini belirler (Casamen, 2005, s.196).

Müşteri istekleri ile teknik karakteristikler arasındaki ilişki ekipteki uzmanlar tarafından belirlenir. Yapılan çalışmada ilişkiler kısmı, teknik karakteristiklerin müşteri isteklerini yeterli olarak kapsayıp kapsamadığını tespit etmekte kullanılır. İlişki matrisi hazırlanırken teknik ve müşteri gereksinimleri kesişme noktaları iki aşamalı bir süreçle incelenip, değerlendirilir (Emiroğlu, 2001, s.45):

- Teknik gereksinimin müşteri gereksinimi üzerinde herhangi bir etkisi var mıdır?

- Eğer bir etki mevcut ise, bu etkinin derecesi nedir? Bu noktada üç farklı düzey tanımlanır; zayıf, orta ve güçlü.

Çalışmada müşteri istekleri ve teknik karakteristikler arasındaki ilişki dereceleri aşağıdaki sembollerle gösterilmiştir.

- Güçlü Dereceli ilişki, 9 rakamı ve $\odot$ şekli ile ifade 
edilmektedir.

- Orta Dereceli ilişki, 3 rakamı O şekli ile ifade edilmektedir.

- Zayıf Dereceli ilişki, 1 rakamı $\triangle$ şekli ile ifade edilmektedir.

"Kalite karakteristikleri" bölümü; belirlenen ürün karakteristiklerinin üretilebilirliğinin tartışılarak bunların ürün prosesine çevrildiği, böylece müşterilerin sesinin anlaşıı ve yorumlanabilir hale getirildiği bölümdür (Özkan, 2002: 59). Kalite karakteristikleri kalite evinin üst kısmında yer alır ve her müşteri isteğini karşılamak için en az bir kalite karakteristiği belirlenmelidir.

2.1.1.6. Planlama matrisi: Planlama matrisi, müşteri şikayetlerini ve rekabete yönelik değerlendirmeleri içerir. Kritik süreçlerin belirlenmesi ve bu süreçlerin planlanmasında KFG takımına yol gösterir. Bu matris her bir müşteri gereksinimi ile ilgili sayısal veriler içermektedir. Planlama matrisinin içeriği her bir KFG çalışmasında, yapılan çalışmanın özelliğine bağlı olarak farklı içeriklere sahip olabilmektedir. KFG takımı, bu matrisi işletmenin ürünlerini geliştirmek ve rekabette daha iyi bir konuma gelmek için kullanır (Çolpan, 2003, s.77).

Planlama matrisinde bulunan "Satış Noktası" sütununda satırlardaki müşteri isteklerinde bir ilerleme yapmanın satışlarda meydana getireceği artışı gösterir ve müşteri taleplerine göre firmadaki uzmanlarca belirlenir. Satışlarda ilerleme potansiyeli ve satış noktası puanları; satışlarda önemli ilerleme: 1,5 , satışlarda ilerleme: 1,2, mevcut durum: 1,0 şeklinde belirlenebilir (Yenginol, 2000, s.61).

Yine planlama matrisinde yer alan yüzde önem derecesi sütunu, her müşteri isteği önem puanının, önem puanı sütununa bölünmesiyle elde edilir. Böylece müşteri isteklerinin yüzde önemleri hesaplanmış olur. Yüzde önem dereceleri hesaplanırken hem müşteri düşünceleri hem de müşteri isteklerinin firma açısından taşıdığı değerin dikkate alındığı gözden kaçırımamalıdır. Önem derecesi matriste ağırlık faktörü ve belirli istatistiksel sonuçları etkileyen katsayı olarak hizmet eder, sayı düşük ise önemlilik derecesi az; yüksek ise yüksek önemlilikte olduğunu ifade eder (Özdil ve Dönmez, 2002, s.174).

2.1.1.7. Teknik tanımlayıcılar: Belirlenen müşteri isteklerinin nasıl yapılabileceğini gösteren teknik özellikleri ifade eden kısımdır (Özdil ve Dönmez, 2002, s.177). Teknik karakteristikler mühendislik gurubu tarafından belirlenir (Emiroğlu, 2001, s.42). Her bir teknik gereksinim için tanımlayıcı ve KFG takımının firmanın mevcut durumuna göre belirlediği hedef değer belirlenir (Clausing ve Pugh, 1991, s.15-25). Bir kalite karakteristiği herhangi bir müşteri isteğinin nasıl karşılanacağını gös- teren bir ifadedir (Yenginol, 2000, s.62).

Bu bölümde müşteri düşünceleri firmanın üretim, tasarım, işletme ile ilgili olarak açıklamada kullanacağı terimlere dönüştürülmektedir (Day, 1998, s.64). Teknik bilgiler kısmının oluşturulmasında belirli bir sıralama yoktur, çünkü matrisin teknik bilgiler kısmı firma, müşteri ve ürün fonksiyonlarına bağlı olarak değişiklikler gösterir (Yıldırım, 2002, s.96). Bu aşamada ürün, mühendislik terminolojisinde yeniden tanımlanır (Savaş, 2002, s.42).

2.1.1.8. Gerçek ve hedef değerler (Teknik kıyaslamalar): Burada mevcut ürünün rekabet değerlendirmesi için teknik detaylar incelenir. Teknik değerlendirmeler kalite evinin altında bir blok halinde gösterilir. Burada ürünler teknik özelliklerine göre 1'den 5'e kadar değerlendirilir (Sharma ve Rawani, 2010). Teknik kıyaslamalar bölümünde, belirlenen her teknik karakteristik için objektif ölçüm değerleri ile hedef değerlere ait aynı karakteristiklerin ölçüm değerleri karşılaştırılır (Yenginol, 2000, s.68).

\subsection{2. Ürün Tasarımı}

Ürün tasarımı aşaması mühendislik bölümü tarafından yönetilir ve yenilikçi fikirleri gerektiren bir aşamadır. Bu aşamada elde edilen veriler geliştirilecek ürünün özelliklerini belirleme amaçlı kullanılır (ciri.org.nz). Teknik gereksinimleri gerçekleştirebilmek için kullanılacak gereksinimler belirlenir. Böylece sütunların öncelikleri belirlenerek hangi parçaların müşteri memnuniyetini sağlamada öncelikli olacağı konusu aydınlanmış olur (Ay, 2003; Akbaba, 2000).

Bununla birlikte ürün tasarım aşamasındayken, önceden belirlenen hedef değerlerin müşteri sesine uygunluğu tekrar kontrol edilir ve mevcut bir olumsuzluk veya müşteri sesine uygunsuzluk varsa iyileştirmeler bu aşamadayken yapılır (Costin, 1999, 326-327).

\subsubsection{Süreç Planlama}

Süreç planlama matrisinde ilk iki sürece bağlı olarak ürünün tüketici taleplerine göre üretim aşaması boyunca kullanılacak süreç parametreleri belirlenir. Bu aşamada meydana gelebilecek aksaklıkları önlemek açısından multidisipliner bir çalışma yapılması oldukça önemlidir çünkü ürünün tüketici taleplerine göre üretilmesinde ekip çalışmasının etkinliği büyük rol oynamaktadır (Shores, 1990, s.266-267).

Oluşturulan bu süreç parametreleri sütunlarda yer alır. Süreç parametrelerinin parça karakteristikleri üzerindeki etkileri ilişki matrisi üzerinde gösterilir ve her biri için bir sütun puanı elde edilir. Yüksek puana sahip süreç parametreleri müşteri isteklerini karşılamada öneme sahip parametrelerdir (Yenginol, 2000). Böylece iyileştirilmesi gereken ürün için sürecin hangi aşama- 
larının yeniden tasarlanması gerekliliğinin söz konusu olup olmadığı ortaya çıkmış olacaktır (Çetin, 2007, s.67).

\subsection{4. Üretim Planlama}

Dördüncü ve son aşama olan üretim planlama matrisi üretim aşamalarının planlamasında kullanılan bir kontrol listesine ve detaylı üretim yöntemlerine dönüştürülür. Süreç planlama matrisinde belirlenmiş olan hedef değerlere göre yapılacak olan üretimin standartları oluşturulur. Böylelikle, üretim planlama adımı ve müşteri sesi arasında bir bağlantı oluşturularak, firmanın tüm fonksiyonlarının tamamıyla müşteri odaklı olması ve buna bağlı olarak tüketici taleplerine tam olarak cevap vermesi sağlanmaktadır. Tüm bu matrislerin oluşturulma amacı, mevcut ürünün tasarımı, üretimi ve müşteriye ulaştırılması konusunda kararlar alınırken tüketici sesinin KFG uygulamasına doğru olarak aktarılabilmesidir. Bu aşamaların oluşturulması sayesinde, bilgi gereksiniminin ve detayların önemi ortaya çıkmakta ve KFG ekibi arasındaki iletişimin gücü artmaktadır. Görülen şu ki, tüketici taleplerinin ürüne yansıtılmasında ürün tasarımı matrisi oldukça önemli bir konuma sahiptir. Bu matriste önceki matrislerden elde edilen bilgiler titizlikle incelenerek tüketici talepleri doğrultusundaki özellikler ürüne yeni tasarımı esnasında eklenmelidir (Nicholas, 1998, s.432-433).

\section{UYGULAMA}

KFG uygulaması, kalite güvence sistemlerinin uygulandığı süt ürünleri üretimi yapan bir işletmede, firmanın tüketimi her geçen gün daha da yaygınlaşan "homojenize yoğurt" ürünü için gerçekleştirilmiştir. Firma, ileri teknolojinin kullanıldığı ve kalite yönetim sistemlerinin uygulandığı tesislerinde 1980 yılından bu yana faaliyet göstermektedir. Trakya'nın köylerinde kurmuş olduğu süt toplama merkezleri sayesinde, üreticiden topladığı sütler en kısa süre içerisinde fabrikaya taşınmakta, sağımı takiben en geç 36 saat içerisinde ürünlere dönüştürülmektedir. Böylece sütün besin değerini koruyarak günlük üretimini gerçekleştirmektedir.

Deneyimli çalışanları ve etkin kalite kontrol laboratuarı ile süt işleme teknolojisinin tüm tekniklerini kullanarak, ürünlerini her geçen gün geliştirmekte, yoğurt, ayran ve tereyağı üretim kapasitesini kalite güvence sistemi standartlarına uygun olarak sürekli arttırmayı hedeflemektedir. Marmara bölgesinde, kendine ait frigofirik klimalı 70 araçlık filoyla geniş bir dağıtım ağına sahip olan firma ürünlerini tüketicisine sağlıklı bir şekilde ulaştırmaktadır. Firmanın ürettiği tüm süt ürünleri Marmara ve Kuzey Ege bölgesindeki büyük market zincirlerinde satışa sunulmaktadır.
KFG uygulamasının gerçekleştirildiği homojenize yoğurdun üretim süreci kısaca şöyle özetlenebilir: Yoğurt üretimine verilecek çiğ süt plakalı ısıtıcılarda 90-95 ${ }^{\circ} \mathrm{C}$ 'de 3-5 dakika, Beç sisteminde $90-95^{\circ} \mathrm{C}$ 'de 10-15 dakika tutularak pastörize edilir. Pastörize edilen süt evaporasyon işlemine tabi tutulur. Evaporatörlerde suyu damıtılarak kuru madde miktarı arttırılır. Homojenize yoğurt üretiminde pastörizasyon ve evaporasyondan sonra işlemler aşağıda belirtilen sırayı izler; Homojenizasyon > Soğutma $\left(40-45^{\circ} \mathrm{C}\right)>$ Kültür ilavesi $>$ Ambalaja dolum > Olgunlaştırma (inkübasyon) > Soğutma > Depolama.

KFG uygulaması ile söz konusu ürün için işletmenin daha iyi kalitede ve müşteri beklentilerini daha iyi karşılayacak düzeyde üretim yapmasının yolları araştırılacaktır. Illk olarak işletmede KFG sürecinin geçerliliği incelenmiştir. Yapılan bu incelemenin sonucunda Kalite Yönetim Sistemlerinden ISO 22000'i etkin bir şekilde uygulayan firmamız için; "KFG yaklaşımının uygulanması bu sistemin destekleyicisi niteliğinde olacaktır" ortak görüşüne varılmıştır. Bu çalışmada kullanılan bilgiler, karşılıklı görüşme yoluyla üretim ve kalite kontrol departmanlarındaki mühendislerden ve işletmenin pazarlama ve halkla ilişkiler departmanlarındaki yetkililerden alınmıştır. "Homojenize yoğurt" için KFG uygulamasının basamakları oluşturulmuş ve en son olarak kalite evinin yorumlanmasına gidilmiştir.

\subsection{Kalite Evi}

Firma kalite bilincine ulaşmış ve ISO 22000 Gıda Güvenliği Sistemini başarıyla uygulamaktadır. Firma genel olarak; mevcut kalitesini korumayı, her geçen gün teknolojik yönünü geliştirerek lider firmalarla eşit düzeye ulaşmayı ve bunların sonucu olarak üretim kapasitesini ve müşteri memnuniyetini arttırmayı hedeflemektedir. KFG çalışmasının yapıldığı işletmede KFG uygulamasının detayları anlatılarak işlemleri yürütebilecek uzmanlardan oluşan bir ekip oluşturulmuştur.

\subsubsection{Tüketici Talepleri ve Önem Düzeyi}

Müşterilerin sesini oluşturan bu yöntemin amacl; işletmenin müşteriler için düşünemediği bazı istek ve gereklilikleri, ürünü bizzat kullanan ve konuyla ilgili geri bildirim yapan müşterilerden elde etmektir.

Tüketici görüşlerinin elde edilmesinde işletmenin pazarlama ve halkla İlişkiler departmanlarındaki mevcut müşteri veri bankası kullanılmıştır. Bu veri bankası son beş yıl içindeki müşterilerden telefon, e-mail ve faks yoluyla gelen tüm talep, şikayet ve memnuniyetleri içeren geri bildirimlerden oluşmaktadır. Veri bankası analiz edilerek, farklı tüketici gruplarının ortak talepleri bir araya getirilmiştir. Firmanın pazarlama ve halkla ilişkiler bölümlerinden toplanmış olan bu tüketici sesi 
Tablo 1: Tüketici Talepleri ve Önem Düzeyleri

\begin{tabular}{|c|c|c|}
\hline \multirow{4}{*}{ Ambalaj } & Tüketici Talepleri & $\begin{array}{c}\text { Önem Düzeyleri } \\
\text { (1: Düs̈ük - 10: } \\
\text { Yüksek) }\end{array}$ \\
\hline \multirow{4}{*}{ Yoğurt } & Kolay Kullanım & 8 \\
\cline { 2 - 3 } & $\begin{array}{c}\text { Geri Dönüşümlü ve } \\
\text { Dikkat Çekici Ambalaj }\end{array}$ & 7 \\
\cline { 2 - 3 } & Aroma & 10 \\
\cline { 2 - 3 } & Kıvam ve renk & 9 \\
\cline { 2 - 3 } & Raf Ömrü & 8 \\
\cline { 2 - 3 } & Hijyenik Ürün & 10 \\
\hline \multirow{3}{*}{ Satış } & Kalite & 7 \\
\cline { 2 - 3 } & Uygun Fiyat & 8 \\
\cline { 2 - 3 } & Yaygın dağıtım ağı & 8 \\
\hline
\end{tabular}

uzman kadro eşliğinde tüketici taleplerine dönüştürülmüştür. Buna göre, kullanıcıların "Homojenize yoğurt" için en çok önem verdiği belirlenen talepler ve bunların önem düzeyleri Tablo 1'de gösterilmiştir.

Tespit edilen talepler incelendiğinde temel beklentilerin yanında fark oluşturabilecek fikirlerin ortaya çıkmadığı tespit edilmiştir. Ancak firma farklı fikirler ortaya çıkmasa da belirlenen bu müşteri talepleri doğrultusunda heyecan verici kaliteyi üretimlerine dâhil ederek müşteri memnuniyetini arttırmayı hedeflemektedir. Bu konuyla ilgili olarak örneğin "Kolay kullanımlı ambalaj" talebi konusunda kapak sisteminin değiştirilerek "vidalı kapak" şeklinde bir uygulamanın denenebileceği görüşü gündeme getirilmiştir. Bu uygulamaya geçebilmek için firmanın mevcut ambalaj stoklarının tükenmesiyle yeni ambalaj taleplerinde kapak sistemiyle ilgili örnek uygulama yapabilecekleri konusunda ortak görüşe varılmıştır.

Bunun yanında tüketicilerin sıklıkla belirttikleri "homojenize yoğurt" ürününün raf ömrüyle ilgili olarak; kapak açıldıktan sonra ürün üzerinde oluşabilen bazı patojenlere karşı müşteriyi uyarmak için ambalajın üzerine açıklayıcı olarak "Açıldıktan sonra 7 gün içerisinde tüketilmelidir" ibaresinin yer almasına karar verilmiştir.
Bu durum özellikle katkısız yoğurt üreten firma için oldukça önem arz eden bir konu olarak değerlendirilmiştir. Yeni parti ambalaj siparişinde bu konunun da gündeme alınacağı belirtilmiştir.

\subsubsection{Hedef Değerlendirmesi}

Tüketici talepleri doğrultusunda değerlendirme yapılırken, kıyaslama için rakip işletme sayısının çok fazla olduğu tespit edilmiştir. Bu nedenle amaç; sektörde lider konuma gelmek olarak belirlenmiş ve firma elde edilebilecek maksimum kaliteye ulaşmayı hedeflemiştir. Böylece homojenize yoğurt için belirlenen hedefler firmanın ulaşmak istediği üst hedefler olarak kabul edilecektir. Buna göre oluşturulan Hedef Değerler Tablo 2'de gösterilmiştir.

Planlama matrisinde "Firmanın Bugünü" sütunu firmanın ürününün firma müşterileri tarafından nasıl algılandığını göstermektedir. Bu örnekte kullanılan ölçek (1: En Kötü, 5: En İyi) şeklindedir. Örneğin birinci müşteri isteği "Kolay Kullanım” açısından firma 4 konumunda algılanmaktadır. Hedef sütunu ise firmanın kendisini nasıl algılamak istediğiyle ilgilidir. Bu örnek incelendiğinde firma ilk müşteri isteğinde 4 konumundadır, firma bu müşteri isteğinde daha iyi bir konumda olmak istediğinden en iyi algılanma konumunu kendisi için hedef olarak seçmiştir. "Ilerleme oranı" sütunu "hedef" sütunun firmanın "bugünkü durumunu" gösteren sütuna bölünmesiyle bulunur. Örneğin uygulamada "Aroma" müşteri isteği için ilerleme oranı 5/4=1,25 şeklinde hesaplanmıştır. "Satış noktası" sütunu müşteri isteklerinde bir ilerleme yapmanın ürünün satışında da ilerleme meydana getirip getirmeyeceğini gösteren bir kavramdır (Arı, 2009). Örneğin homojenize yoğurt üretiminde yoğurdun "Aroma" özelliğinin iyi olmasının ya da müşteri tarafından bilinen alışılmış tat ve kokunun korunmasının müşteri taleplerini olumlu yönde etkileyeceği görülmektedir.

Önem puanı sütunu; önem derecesi, ilerleme oranı ve satış noktası puanlarının çarpımından oluşur. Uy-

Tablo 2: Hedef Değerler

\begin{tabular}{|l|c|c|c|c|c|c|c|}
\hline Müşteri İstekleri & $\begin{array}{c}\text { Önem } \\
\text { Derecesi }\end{array}$ & $\begin{array}{c}\text { Firma } \\
\text { Bugün }\end{array}$ & Hedef & İlerleme Oranı & Satı̧ Noktası & Önem Puanı & $\%$ Önem \\
\hline Kolay Kullanım & 8 & 4 & 5 & 1,25 & 1 & 10 & 8 \\
\hline $\begin{array}{l}\text { Geri Dönüşümlü ve } \\
\text { Dikkat Çekici Ambalaj }\end{array}$ & 7 & 5 & 5 & 1 & 1 & 7 & 5,6 \\
\hline Aroma & 10 & 4 & 5 & 1,25 & 1,5 & 18,75 & 15 \\
\hline Kıvam ve renk & 9 & 4 & 5 & 1,25 & 1,2 & 13,5 & 11 \\
\hline Raf Ömrü & 8 & 3 & 4 & 1,3 & 1,2 & 12,48 & 10 \\
\hline Hijyenik Ürün & 10 & 5 & 5 & 1 & 1,5 & 15 & 12 \\
\hline Kalite & 7 & 4 & 4 & 1 & 1,2 & 8,4 & 6,7 \\
\hline Uygun Fiyat & 8 & 3 & 4 & 1,3 & 1,5 & 15,6 & 12,5 \\
\hline Yaygın dağııım ağı & 8 & 2 & 4 & 2 & 1,5 & 24 & 19,2 \\
\hline TOPLAM & & & & & & 124,73 & 100 \\
\hline
\end{tabular}


Tablo 3: Teknik Gereksinimler

\begin{tabular}{|c|c|c|c|c|c|c|c|c|c|c|c|c|c|c|c|}
\hline $\begin{array}{l}\text { Müşteri } \\
\text { İstekleri }\end{array}$ & 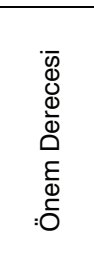 & 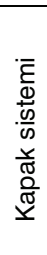 & 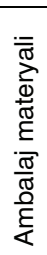 & 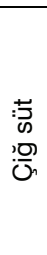 & 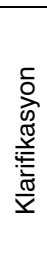 & 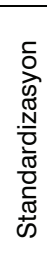 & 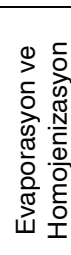 & 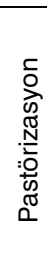 & 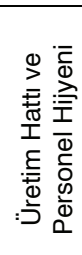 & 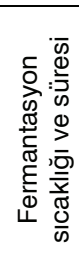 & 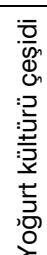 & 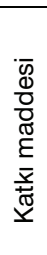 & 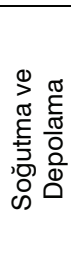 & 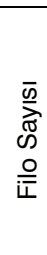 & 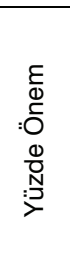 \\
\hline $\begin{array}{c}\text { Kolay } \\
\text { Kullanım }\end{array}$ & 8 & $\odot$ & 0 & & & & & & & & & & & & 8 \\
\hline $\begin{array}{c}\text { Geri } \\
\text { Dönüşümlü } \\
\text { ve Dikkat } \\
\text { Çekici } \\
\text { Ambalaj }\end{array}$ & 7 & & ○ & & & & & & & & & & & & 5,6 \\
\hline Aroma & 10 & & & $\odot$ & $\circ$ & $\odot$ & $\odot$ & 0 & & $\odot$ & $\odot$ & $\odot$ & 0 & & 15 \\
\hline $\begin{array}{l}\text { KIvam ve } \\
\text { renk }\end{array}$ & 9 & & & $\odot$ & $\odot$ & $\odot$ & $\odot$ & 0 & & $\odot$ & $\odot$ & $\odot$ & $\mathrm{O}$ & & 11 \\
\hline Raf Ömrü & 8 & $\odot$ & 0 & $\odot$ & $\odot$ & $\triangle$ & $\odot$ & $\odot$ & $\odot$ & $\odot$ & $\odot$ & $\odot$ & 0 & & 10 \\
\hline $\begin{array}{l}\text { Hijyenik } \\
\text { Ürün }\end{array}$ & 10 & $\circ$ & $\mathrm{O}$ & $\odot$ & $\odot$ & 0 & 0 & ○ & $\odot$ & $\triangle$ & $\odot$ & $\odot$ & $\odot$ & & 12 \\
\hline Kalite & 7 & & & 0 & & $\mathrm{O}$ & $\odot$ & $\mathrm{O}$ & & $\odot$ & ○ & $\odot$ & $\triangle$ & & 6,7 \\
\hline $\begin{array}{c}\text { Uygun } \\
\text { Fiyat }\end{array}$ & 8 & 0 & $\triangle$ & $\odot$ & & $\odot$ & $\odot$ & $\triangle$ & & & $\odot$ & 0 & & $\odot$ & 12,5 \\
\hline $\begin{array}{c}\text { Yaygıı } \\
\text { Dağıtım Ağı }\end{array}$ & 8 & & & & & & & & & & & & & $\odot$ & 19,2 \\
\hline $\begin{array}{l}\text { Teknik } \\
\text { önem } \\
\text { derecesi }\end{array}$ & $\sum 4948$ & م & 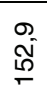 & 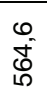 & $\stackrel{\widetilde{m}}{+}$ & $\begin{array}{l}0 \\
\stackrel{0}{N} \\
\frac{y}{y}\end{array}$ & $\begin{array}{l}\infty \\
\text { ஸ్ } \\
\text { గn }\end{array}$ & $\begin{array}{l}0 \\
\infty \\
0 \\
\infty\end{array}$ & $\stackrel{\infty}{\circ}$ & $\begin{array}{l}\text { m } \\
0^{-} \\
\text {ల్ }\end{array}$ & $\begin{array}{l}\infty \\
\delta^{+}\end{array}$ & $\begin{array}{l}\infty \\
\text { N్ } \\
\text { ஸे }\end{array}$ & กิ & $\begin{array}{l}\stackrel{\infty}{ } \\
\stackrel{N}{N}\end{array}$ & 100 \\
\hline $\begin{array}{c}\text { Normalize } \\
\text { teknik } \\
\text { önem }\end{array}$ & 100 & $\stackrel{N}{\sigma}$ & $\bar{m}$ & $\stackrel{\sigma_{-}}{F}$ & $\hat{\infty}$ & $\stackrel{+}{+}$ & $\begin{array}{l}\infty \\
\overbrace{}^{\infty}\end{array}$ & $\stackrel{N}{6}$ & 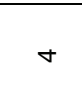 & $\infty$ & $\begin{array}{l}\stackrel{N}{\sim} \\
\stackrel{n}{n}\end{array}$ & $\hat{0}$ & $\stackrel{n}{*}$ & $\stackrel{\infty}{\infty}$ & \\
\hline
\end{tabular}

gulamada "Aroma" müşteri isteği için önem puanı 10 x 1,25 x 1,5 =18,75 olarak belirlenmiştir. Önem puanlarının normalize edilmesiyle de yüzde önem sütunu elde edilmektedir. Yüzde önem sütunu her bir müşteri isteğinin toplam müşteri isteği içindeki yüzde önemini gösteren değerdir (Arı, 2009). Oluşturulan Hedef değerler (Tablo 2) tablosuna göre satış noktası puanı 1,5 olan "Aroma", "Hijyenik Ürün", "Uygun Fiyat" ve "Yaygın Dağıtım Ağı" müşteri İsteklerine önem verilirse firmanın ilerleme kaydedilebileceği anlaşılmaktadır.

\subsubsection{Tüketici Taleplerine Yönelik Teknik Gereksinimlerin Belirlenmesi}

Tablo 3'te firmanın tüketici talepleri doğrultusunda belirlenen teknik gereksinimler arasındaki ilişki gösterilmektedir. Her bir teknik gereksinimin tüketici talebini karşılamadaki etkisini belirleyebilmek için teknik önem derecesi hesaplanır. Teknik önem derecesi; her bir teknik karakteristik için planlama matrisinde hesaplanan "yüzde önem dereceleri" ile "ilişki puanları" çarpımının toplanması yöntemiyle hesaplanır. Örneğin birinci teknik karakteristik için teknik önem derecesi söyle hesaplanır: $(8 \times 9)+(10 \times 9)+(12 \times 1)+(12,5 \times 3)=307,5$

Teknik önem derecelerine göre nispeten yüksek olan teknik karakteristikler gelişmede öncelik tanınacak teknik karakteristiklerdir. Müşteri istekleri ile teknik karakteristikler arasında yeterli sembolün olmaması veya zayıf ilişkinin çok olması durumunda, müşteri talep ve gereksinimlerini karşılayacak bir tasarımın uygulanmadığı düşünülür. Tablo 3'te ilişkiler kısmı incelendiğinde güçlü ilişkilerin çokluğu müşteri beklentilerinin yeterli derecede ifade edildiğini göstermektedir (Arı, 2009). 


\subsubsection{Teknik Gereksinimlerin Analizi}

Bu aşamada müşteri isteklerini karşılayacak olan teknik karakteristikler sektörde lider konuma gelme açısından irdelenmiştir. Teknik karşılaştırmaların yapılması aşamasında yine işletmedeki uzman kişilerden konu hakkında bilgi alınmıştır.

Örneğin "çiğ süt" teknik karakteristiği için işletmenin gıda mühendisi ile görüşüldü ve firmanın günde 85 ton süt işlediği öğrenildi. Firma üretim hacmini genişletmek için günlük süt işleme miktarını arttırılabileceği-

Tablo 4: Teknik Gereksinimlerin Analizi

\begin{tabular}{|c|c|c|c|c|c|c|c|c|c|c|c|c|c|c|c|c|}
\hline $\begin{array}{l}\text { Müşteri } \\
\text { İstekleri }\end{array}$ & 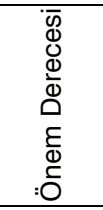 & 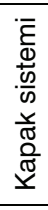 & 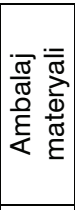 & 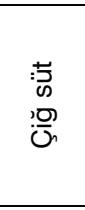 & 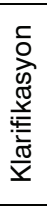 & 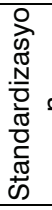 & 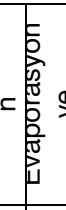 & 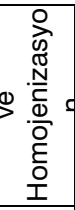 & 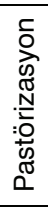 & 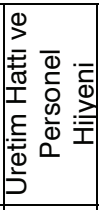 & 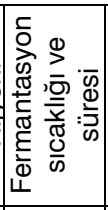 & 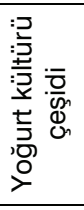 & 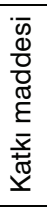 & 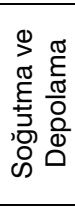 & 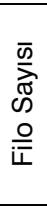 & 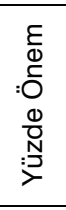 \\
\hline $\begin{array}{c}\text { Kolay } \\
\text { Kullanım }\end{array}$ & 8 & ○ & $\mathrm{O}$ & & & & & & & & & & & & & 8 \\
\hline $\begin{array}{c}\text { Geri } \\
\text { Dönüşümlü } \\
\text { ve Dikkat } \\
\text { Çekici } \\
\text { Ambalaj } \\
\end{array}$ & 7 & & ○ & & & & & & & & & & & & & 5,6 \\
\hline Aroma & 10 & & & ○ & ○ & ○ & & ○ & $\mathrm{O}$ & & ○ & ○ & ○ & $\mathrm{O}$ & & 15 \\
\hline $\begin{array}{l}\text { Kivam ve } \\
\text { renk }\end{array}$ & 9 & & & ○ & ○ & ○ & & ○ & $\mathrm{O}$ & & ○ & ○ & ○ & $\mathrm{O}$ & & 11 \\
\hline Raf Ömrü & 8 & ○ & $\mathrm{O}$ & ○ & ○ & $\triangle$ & & ○ & ○ & ○ & $\odot$ & ○ & ○ & $\mathrm{O}$ & & 10 \\
\hline $\begin{array}{c}\text { Hijjyenik } \\
\text { Ürün }\end{array}$ & 10 & ○ & $\mathrm{O}$ & ○ & ○ & $\mathrm{O}$ & & $\mathrm{O}$ & ○ & ○ & $\triangle$ & ○ & ○ & ○ & & 12 \\
\hline Kalite & 7 & & & $\mathrm{O}$ & & 0 & & ○ & $\mathrm{O}$ & & $\odot$ & ○ & ○ & $\triangle$ & & 6,7 \\
\hline $\begin{array}{c}\text { Uygun } \\
\text { Fiyat }\end{array}$ & 8 & $\mathrm{O}$ & $\triangle$ & ○ & & ○ & & ○ & $\triangle$ & & & ○ & $\mathrm{O}$ & & ○ & 12,5 \\
\hline $\begin{array}{c}\text { Yaygın } \\
\text { Dağıtım } \\
\text { Ağı }\end{array}$ & 8 & & & & & & & & & & & & & & ○ & 19,2 \\
\hline $\begin{array}{c}\text { Teknik } \\
\text { önem } \\
\text { derecesi }\end{array}$ & $\sum 4948$ & న̊ & $\begin{array}{l}\text { ๑̊ } \\
\text { Nิ }\end{array}$ & 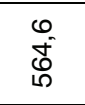 & ঙิ & $\frac{d}{i}$ & & $\stackrel{\infty}{N}$ & $\begin{array}{l}0 \\
\infty \\
\text { ○े }\end{array}$ & $\stackrel{\infty}{\sigma}$ & $\begin{array}{l}\text { m } \\
\text { क़ }\end{array}$ & $\stackrel{\infty}{\mathbb{\delta}^{-}}$ & $\begin{array}{l}\infty \\
\text { స్ } \\
\text { กิ }\end{array}$ & กิ & $\begin{array}{l}m \\
\stackrel{m}{\infty} \\
\stackrel{N}{N}\end{array}$ & 100 \\
\hline $\begin{array}{c}\text { Normalize } \\
\text { teknik } \\
\text { önem }\end{array}$ & 100 & $\underset{0}{O}$ & $\overline{\bar{m}}$ & $\frac{\nabla}{\sigma}$ & $\hat{\infty}$ & $\stackrel{+}{\infty}$ & & $\stackrel{\infty}{\infty}$ & $\underset{0}{\sim}$ & $\nabla$ & $\infty$ & $\begin{array}{c}N \\
N \\
\end{array}$ & $\stackrel{0}{0}$ & $\stackrel{10}{\forall}$ & $\begin{array}{l}\infty \\
\infty \\
0\end{array}$ & \\
\hline $\begin{array}{l}\text { Ölçüm } \\
\text { Birimi }\end{array}$ & & & & 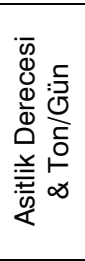 & $\begin{array}{l}\bar{E} \\
\text { ○ } \\
\frac{O}{\text { Oે }}\end{array}$ & 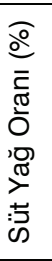 & & 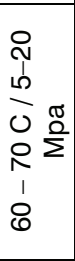 & $\begin{array}{l}\frac{1}{0} \\
0 \\
1 \\
1 \\
0 \\
0 \\
10 \\
0\end{array}$ & 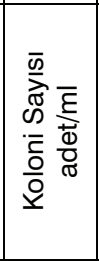 & 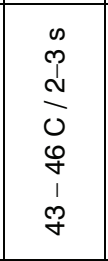 & 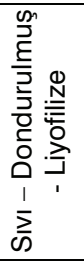 & ర్ & $\begin{array}{c}0 \\
0 \\
0 \\
0 \\
1 \\
0 \\
0 \\
\ddot{0} \\
\ddot{0}\end{array}$ & $\frac{+}{\frac{0}{0}}$ & \\
\hline Bugün & & & & 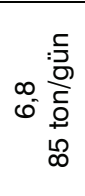 & 10 & $\stackrel{\infty}{\infty}$ & o & $\begin{array}{r}\sum_{0}^{\frac{0}{2}} \\
\frac{0}{0} \\
0 \\
0 \\
0\end{array}$ & $\begin{array}{l}\frac{y}{0} \\
0 \\
\frac{0}{1} \\
1 \\
0 \\
0 \\
0 \\
0\end{array}$ & $\stackrel{m}{\square}$ & 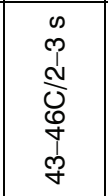 & 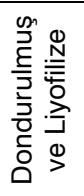 & 0 & $\begin{array}{l}0 \\
0 \\
1 \\
0 \\
0\end{array}$ & 요 & \\
\hline Hedef & & & & 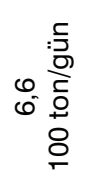 & $m$ & $m$ & $\propto$ & $\frac{\sum_{0}^{\frac{\pi}{2}}}{\frac{10}{1}}$ & $\begin{array}{l}\frac{y}{0} \\
\frac{0}{1} \\
\frac{1}{0} \\
0 \\
0\end{array}$ & 으 & 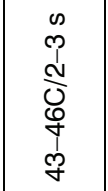 & 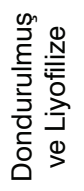 & 0 & $\begin{array}{l}0 \\
0 \\
1 \\
0 \\
0 \\
0\end{array}$ & 응 & \\
\hline
\end{tabular}


ne inanarak 100 ton/gün olarak belirlemiştir. Firmanın sektörde daha yüksek rekabet gücüne ulaşabilmesi için gerekli veriler Tablo 4'te gösterilmiştir.

Tablo 4'e bakıldığında firmanın "çiğ sütün asitlik derecesi, klarifikasyon (sütün temizlenmesi), üretim hattı ve personel hijyeni" teknik karakteristiklerindeki hedef değerlerini düşürmesi ve "evaporasyon (sütün kuru madde miktarını arttırmak için suyun buharlaştıııması), standardizasyon ve homojenizasyon" teknik karak- teristiklerindeki hedef değerlerini yükseltmesi durumunda sektörde daha güçlü bir pozisyonda rekabet edebileceği sonucu ortaya çıkmaktadır.

\subsubsection{Kalite Evinin Oluşturulması}

Son olarak kalite evinin oluşturulması işlemi tamamlanmaktadır. Yapılan bu çalışmada ilk olarak mevcut ürünün belirlenmesi ve ardından tüketici taleplerinin derlendirilmesinden sonra üç farklı konuda tüketici taleplerinin yoğunlaştığı tespit edilmiştir. Üretim aşama-

Tablo 5: Kalite Evi

\begin{tabular}{|c|c|c|c|c|c|c|c|c|c|c|c|c|c|c|c|c|c|c|c|c|}
\hline $\begin{array}{l}\text { Müşteri } \\
\text { İstekleri }\end{array}$ & 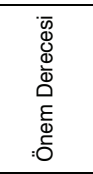 & 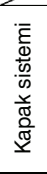 & 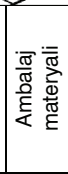 & $\begin{array}{l}: 5 \\
\text { : } \\
\text { on } \\
0.00\end{array}$ & 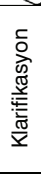 & 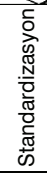 & 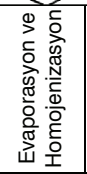 & 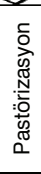 & 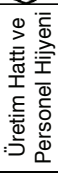 & 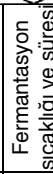 & 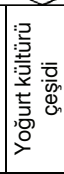 & 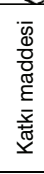 & 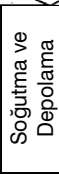 & $\begin{array}{l}\bar{\infty} \\
\text { స్ } \\
\infty \\
\text { 은 }\end{array}$ & 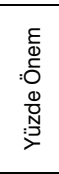 & 岧 & 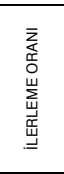 & 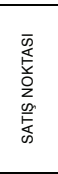 & 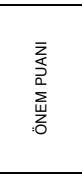 & 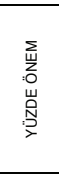 \\
\hline $\begin{array}{c}\text { Kolay } \\
\text { Kullanım }\end{array}$ & 8 & $\odot$ & o & & & & & & & & & & & & 8 & 5 & 1,25 & 1 & 10 & 8 \\
\hline $\begin{array}{c}\text { Geri } \\
\text { Dönüşümlü } \\
\text { ve Dikkat } \\
\text { Çekici } \\
\text { Ambalaj }\end{array}$ & 7 & & $\odot$ & & & & & & & & & & & & 5,6 & 5 & 1 & 1 & 7 & 5,6 \\
\hline Aroma & 10 & & & $\odot$ & $\odot$ & $\circ$ & $\odot$ & 0 & & $\odot$ & $\odot$ & $\odot$ & 0 & & 15 & 5 & 1,25 & 1,5 & 18,75 & 15 \\
\hline $\begin{array}{c}\text { Kivam ve } \\
\text { renk }\end{array}$ & 9 & & & $\odot$ & $\odot$ & $\odot$ & $\odot$ & 0 & & $\odot$ & $\odot$ & $\odot$ & 0 & & 11 & 5 & 1,25 & 1,2 & 13,5 & 11 \\
\hline Raf Ömrü & 8 & $\odot$ & $\mathrm{O}$ & $\odot$ & $\circ$ & $\triangle$ & $\odot$ & $\odot$ & $\odot$ & $\odot$ & $\odot$ & $\odot$ & $\mathrm{O}$ & & 10 & 4 & 1,3 & 1,2 & 12,48 & 10 \\
\hline $\begin{array}{l}\text { Hijyenik } \\
\text { Ürün }\end{array}$ & 10 & $\odot$ & 0 & $\odot$ & $\odot$ & o & 0 & $\odot$ & $\odot$ & $\Delta$ & $\odot$ & $\odot$ & $\odot$ & & 12 & 5 & 1 & 1,5 & 15 & 12 \\
\hline Kalite & 7 & & & 0 & & 0 & $\odot$ & 0 & & $\odot$ & $\odot$ & $\odot$ & $\triangle$ & & 6,7 & 4 & 1 & 1,2 & 8,4 & 6,7 \\
\hline $\begin{array}{l}\text { Uygun } \\
\text { Fiyat }\end{array}$ & 8 & 0 & $\triangle$ & $\odot$ & & $\odot$ & $\odot$ & $\triangle$ & & & $\odot$ & 0 & & $\odot$ & 12,5 & 4 & 1,3 & 1,5 & 15,6 & 12,5 \\
\hline $\begin{array}{c}\text { Yaygın } \\
\text { Dağttım } \\
\text { Ağı }\end{array}$ & 8 & & & & & & & & & & & & & $\odot$ & 19,2 & 4 & 2 & 1,5 & 24 & 19,2 \\
\hline $\begin{array}{l}\text { Teknik } \\
\text { önem } \\
\text { derecesi }\end{array}$ & $\sum 4948$ & $\begin{array}{l}\stackrel{n}{\circ} \\
\stackrel{0}{0}\end{array}$ & ָ̊ำ & $\begin{array}{l}0 \\
\text { 通 }\end{array}$ & $\stackrel{\widetilde{g}}{q}$ & $\begin{array}{l}0 \\
\stackrel{0}{j} \\
\dot{f}\end{array}$ & 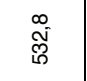 & $\begin{array}{l}0 \\
\infty^{\circ} \\
\bar{m}^{-1}\end{array}$ & $\stackrel{\infty}{\circ}$ & 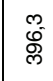 & $\begin{array}{l}\infty \\
\text { ¿ें }\end{array}$ & 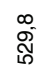 & $\hat{\tilde{N}}$ & @ొ & 100 & & & & 124,73 & 100 \\
\hline $\begin{array}{c}\text { Normalize } \\
\text { teknik } \\
\text { önem }\end{array}$ & 100 & $\stackrel{N}{0}$ & $\bar{m}$ & $\stackrel{\nabla}{=}$ & $\hat{\infty}$ & $\stackrel{+}{+}$ & $\begin{array}{l}\infty \\
\stackrel{\infty}{+}\end{array}$ & $\underset{0}{N}$ & $\sigma$ & $\infty$ & $\stackrel{\widetilde{N}}{\stackrel{N}{\sim}}$ & $\hat{0}$ & $\stackrel{\circ}{\sim}$ & $\stackrel{\infty}{\sigma^{-}}$ & & & & & & \\
\hline $\begin{array}{l}\text { Ölçüm } \\
\text { Birimi }\end{array}$ & & & & 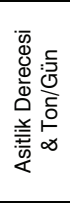 & $\begin{array}{l}\bar{\varepsilon} \\
8 \\
\bar{c} \\
\bar{\varepsilon}\end{array}$ & 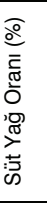 & 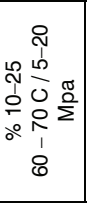 & $\begin{array}{l}5 \\
0 \\
0 \\
0 \\
1 \\
0 \\
0 \\
80\end{array}$ & 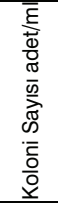 & 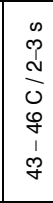 & 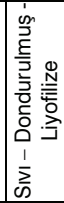 & $\stackrel{\square}{E}$ & $\begin{array}{l}0 \\
0 \\
0 \\
0 \\
1 \\
0 \\
0 \\
\ddot{0} \\
\ddot{\infty}\end{array}$ & $\frac{\vec{\sigma}}{4}$ & & & & & & \\
\hline Bugün & & & & 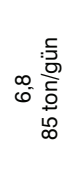 & م & $\stackrel{\infty}{\sim}$ & $\stackrel{\substack{\sum_{0}^{0} \\
0}}{\simeq}$ & $\begin{array}{l}5 \\
0 \\
0 \\
1 \\
10 \\
0 \\
0 \\
8\end{array}$ & $\stackrel{m}{\longrightarrow}$ & 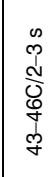 & 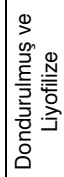 & 0 & $\begin{array}{l}0 \\
0 \\
1 \\
1 \\
0 \\
0\end{array}$ & $R$ & & & & & & \\
\hline Hedef & & & & 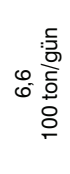 & $m$ & m & 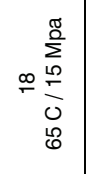 & 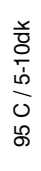 & 우 & 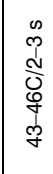 & 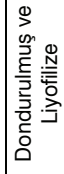 & 0 & $\begin{array}{l}0 \\
0 \\
1 \\
1 \\
0 \\
0\end{array}$ & 음 & & & & & & \\
\hline
\end{tabular}


sında dikkate alınacak olan bu tüketici talepleri şu başlıklar altında toplanmıştı;; Ambalaja dair olan talepler "Kolay kullanımlı, geri dönüşümlü ve dikkat çekici ambalaj", ürünün özelliklerine has olan talepler "aroması, kıvamı, rengi, raf ömrü, hijyenik şartlar altında üretilmesi ve kalitesinden ödün vermemesi" ve son olarak da satışa dair olan tüketici talepleri "uygun fiyat ve yaygın dağııım ağına sahip olması" bilgilerine ulaşı ımıştır. Bu taleplerin dikkate alınmasının nedeni önem puanı en yüksek olan müşteri gereksinimleri arasında yer almasıdır. Böylece firma tüketici taleplerini uygulayarak hem satış noktası olarak rekabet edilebilecek hem de kalitesinden ödün vermemiş olacaktır. Firma için oluşturulan kalite evi Tablo 5'te gösterilmiştir.

Örneğin bu teknik karakteristiklerin teknik önem derecelerinden biri incelenecek olursa üretimde kullanılan "çiğ sütün kalitesi ve yoğurt kültürü çeşidi" teknik karakteristiklerinin geliştirilmesi gereken özellikler arasında olduğu ve sektör karşısında rekabet avantajı kazandıracak olan teknik karakteristikler olduğu söylenebilir. Kısacası firma "raf ömrü" müșteri isteğini, "çiğ sütün kalitesi ve kullandığı yoğurt kültürü çeşidi" teknik karakteristiklerini geliştirerek karşılayabilirse daha kaliteli ürünler üreterek pazarda daha iyi konuma gelebilecektir. Bunun gibi diğer değerler de tablodan yorumlanarak firmanın rekabet avantajı elde edebileceği konular belirlenebilir.

\section{SONUÇ}

Teknolojik gelişmelerin hızlanması, sosyal etkileşimin artması, eğitim seviyesinin yükselmesi gibi etkenler bilinçli tüketici sayııını her geçen gün arttırmaktadır. Bu durum, gıda sektöründe faaliyet gösteren işletmeleri büyük ölçüde etkilemektedir. Son yıllarda KFG tekniğinin özellikle kalite güvence yönetimini benimseyen gıda işletmelerinde de uygulanmaya başlanması, sektörde müşteri sesinin dinlenmesi açısından olumlu bir gelişmedir. KFG yaklaşımı işletmelere, müşteri odakIı bir anlayış geliştirme, müşteri beklentilerini daha iyi analiz etme, ürünün kalitesi ve güvenilirliğini arttırma, müşteri tatminini sağlama, müşteri-işletme ilişkilerini geliştirme ve işletmeye uzun vadeli düşünme anlayışı kazandırılabilmektedir.

Gıda sektörü kaliteli yaşam standardını etkilemesi nedeniyle itina gösterilmesi gereken bir alandır. KFG, gıda işletmelerinde kaliteli üretime, müşseriye ve işletme kültürüne bakışı önemli ölçüde değiştirebilecek bir yaklaşımdır. Müşteri ihtiyaçlarına uygun ürünlerin üretimi ve kaliteyi arttırma konusunda, her geçen gün önemi daha da artan toplam kalite yönetimi felsefesinin alt dallarından biri olan kalite güvence sistemi ile birlikte KFG yaklaşımının bir bütün olarak uygulanması gıda işletmelerinde mevcut ürünün geliştirilmesi açısından uygun bir yöntem olacaktır. Gıda sektöründe sürekli başarıyı ve farklı bakış açılarını elde etmek isteyen firmalar müşteri talepleri ve gereksinimleri hakkında bilgi sahibi olabilmek için sürekli izlemeyi sağlayacak sistematik bir süreç geliştirmelidirler. Bu süreç zarfında elde edilen bilgilerle firma, bir yandan müşteri talep ve gereksinimlerine sürekli cevap verebilecek konuma ulaşırken diğer yandan teknolojisini hızla yenileyerek sürekli gelişme gösterebilecektir.

Kalite güvence sistemlerinin gıda işletmelerinde uygulanıyor olması kalitenin yükseltilmesi ve rekabette üstünlük sağlanması açısından da yol gösterici destek sistemler olduğu söylenebilir. Bununla beraber müşteri sesinin dinlenmesini öngören KFG yaklaşımının benimsenmesi hızla değişen ve gelişen gıda sektöründeki firmaların stratejik teoriler geliştirmesi konusunda kolaylık sağlayacaktır. KFG uygulamalarının benimsenmesi halinde, ürünün müşteri tarafından talep gören özelliklerinin ön plana çıkartılarak firmanın avantajlı konuma gelmesi sağlanabilecektir. Bunun yanında KFG uygulaması gerçekleştirilirken matrislerin oluşturulması aşamasında yalnızca müşteri taleplerinin bu matrislerde yer alması, yönetilmesi güç matrislerin oluşmasına neden olabileceğinden bu noktada firmadaki uzmanların görüşlerinden faydalanılarak yönetilebilir matrislerin oluşturulması sağlanmalıdır. Ayrıca KFG yaklaşımını ilk defa uygulayacak bir işletme için matrisleri daha uygulanabilir ve basit düzeyde tutması işletmenin bu konuda deneyim kazanmasını sağlayarak bir sonraki KFG uygulamasında daha profesyonel yaklaşımlar geliştirmeleri konusunda öncülük edebilecektir.

Bu çalışmada tüketimi yaygınlaşan homojenize yoğurt üretimi yapan bir süt ürünleri firmasında KFG yaklaşımı uygulanmaya çalışılmıştır. KFG yaklaşımı uygulanırken müşteri sesine göre talepler belirlenmiş ve pazardaki rekabet gücünü arttırmak için tüm departmanlar arasında multidisipliner bir çalışma yöntemi geliştirilerek teknik gereksinimler ortaya çıkarılmışıı. Mevcut ürünün KFG uygulaması ile geliştirilmesi sürecinde; müşterilerin talepleriyle ilgili analizler gıda sektörüne has özellikler dikkate alınarak değerlendirilmiş ve "kalite güvence yaklaşımını destekleyecek nitelikli çözümler üretilmesi konusunda yararlı çözüm teknikleri üretilebilecektir" fikri benimsenmiştir. Böylece hatasız üretimin gerçekleştirilmesi için her aşamanın sürekli izlenmesi, yaygın dağııım ağının oluşturulması için üretim planının geliştirilmesi ve etkin bir şekilde yönetilmesi, teknoloji ve rekabet şartlarına uygun hareket edebilmek için stratejiler geliştirilmesi ile müşteri memnuniyetinin ve dolayısıyla talebin artması sağlanabilecektir.

Kalite güvence sistemlerini uygulayan gıda firmala- 
rı KFG yaklaşımını da benimsedikleri takdirde müşteri sesini üretime daha hızlı taşıyabileceklerdir. Böylece talebe göre üretim yaparak rekabette üstünlük kazanabileceklerdir. Bu açıdan düşünüldüğünde KFG yaklaşımı oldukça önemlidir ve etkin bir şekilde uygulamaya konulduğu takdirde firmaya sağlayacağı etkileri uzun vadeli olacaktır.

KFG uygulaması yapılan işletmede, üretimi yapılan homojenize yoğurt için en çok talep gören isteklerden biri olan fiyatın uygunluğu için öncelikle ülkemizde yerli sermaye ile uygulaması yapılmayan "starter kültür" üretiminin yapılması yabancı ülkelere bağımlılığı azaltacak ve bununla beraber maliyetin büyük ölçüde düşmesini sağlayacak yöntemler arasındadır.

KFG uygulaması sonucunda, işletmede kalitenin sürekli arttırılmasının işletmenin tüm departmanlarının multidisipliner ve müşteri odaklı bir karar mekanizması geliştirmeleri ile mümkün olabileceği vurgulanmıştır. Bununla birlikte KFG yaklaşımının temel niteliğini ifade eden "müşteri odaklı bir işletme" olmaları için halkla ilişkiler ve pazarlama departmanlarının müşterilerden daha etkin bilgi almalarını sağlayacak anlaşılır ve kolay uygulanabilir bir anket formu oluşturmalarının, müşteri sesinin işletmeye taşınmasını kolaylaştıracağı yönünde ortak görüş birliğine varılmıştır.

Yapılan bu araştırmada KFG yaklaşımı, süt ürünleri endüstrisinde müşteriler tarafından günlük ihtiyaçlarını karşılamak için en yaygın olarak tercih edilen homojenize yoğurt üzerinde uygulanmıştır. Araştırmada Homojenize yoğurt ürünü için oluşturulan kalite evinin, bir takım değişikliklerle diğer gıda ürünlerinin üretim süreçlerinde de uygulanabilinecek özellikte olduğu düşünülmektedir. Araştırmada firmanın halkla ilişkiler ve pazarlama bölümünden elde edilen müşteri verileri değerlendirilerek KFG yaklaşımı için firmanın nasıl bir yol izleyeceği açıklanmıştır. Konuyla ilgili yapılacak olan daha sonraki araştırmalarda ise farklı bir gıda ürünü için KFG yaklaşımının uygulanması bu yaklaşımın gıda sektörü tarafından benimsenerek daha yaygın kullanılmasını sağlayacaktır. Ayrıca KFG yaklaşımının gıda sektöründe uygulanan Kalite Güvence Sistemleri ve TKY gibi yaklaşımların bir tamamlayıcısı niteliğinde olduğu söylenebilir. Bu araştırma süt ürünleri sektöründe yapılan diğer KFG araştırmalarını endüstriyel düzeyde destekleyici niteliktedir.

\section{KAYNAKLAR}

Abasov, V. (2002) "Mamul ve Mamul Üretim Sisteminin Geliştirilmesinde Kalite Fonksiyon Göçeriminin Rolü ve Bir Uygulama”, Yayınlanmamış Doktora Tezi, Dokuz Eylül Üniversitesi Sosyal Bilimler Enstitüsü, İzmir.

Adrian, J.J. (1995) Total Quality Management. The Illionis Department of Transportation, Peoria, Illinois.

Akbaba, A. (2000) "Kalite Fonksiyon Göçerimi Metodu ve Hizmet İsletmelerine Uyarlanması”, Dokuz Eylül Üniversitesi Sosyal Bilimler Enstitüsü Dergisi, 2(3).

Akao, Y. (1990) Quality Function Deployment, Massachusetts, New England, USA, Productivity Press,.

Arı, S. (2006) "Müşteri Beklentilerini Ürün Karakteristiklerine Dönüştürme Aracı Olarak Kalite Fonksiyon Göçerimi ve Bir Gıda İsletmesinde Uygulama Denemesi”, Yayınlanmamış Yüksek Lisans Tezi, Selçuk Üniversitesi Sosyal Bilimler Enstitüsü, Konya.

Ay, M. (2003) "Kalite Fonksiyon Göçerimi ve Uygulama Örneği”, Yayınlanmamış Yüksek Lisans Tezi, Pamukkale Üniversitesi Sosyal Bilimler Enstitüsü, Denizli.

Besterfield, D.H., Besterfield, M.C., Besterfield, G.H., ve Besterfield, S.M. (1999) Total Quality Management, 2nd Edition., Upper Saddle River-New Jersey, USA Prentice- Hall Inc.

Benner, M., Linnemann, A.R., Jongen, W.M.F. ve Folstar, P. (2003) "Quality Function Deployment (QFD) - Can It Be Used to Develop Food Products?", Food Quality and Prefe- rence, 14: 327-339.

Bouchereau, V. ve Rowlands, H. (2000) "Methods and Techniques to Help Quality Function Deployment (QFD)", Benchmarking: An International Journal, 7 (1):8-19.

Casamen, R., Mata, M. ve Mantilla, J. (2005) "Using QFD in The Desing Process of a Trailer Office", 11th. International Symposium on Quality Function Deployment, Kuşadası.

Clausing, D. ve Pugh, S. (1991) "Enhanced Quality Function Deployment", Proceedings of The Design Productivity International Conference, Massachusetts, ss. 15-25, New England, USA.

Cohen, L. (1995) Quality Function Deployment, How to Make QFD Work For You, Addison Wesley, Reading, Massachusetts.

Compton, W.D. (1999) Mühendislik ve Teknoloji Yönetimi, (Çeviren: Gül, E. Okudan), 1. Baskı, İstanbul, Beta Yayınları.

Costa, A.I.A., Dekker, M. ve Jongen, W.M.F. (2001) "Quality Function Deployment in The Food Industry: A Review", Trends in Food Science \& Technology, 11 (9-10): 306-314.

Costin, H. (1999) Strategies for Quality Improvement, Second Edition, USA ,Dryden Press,.

Çetin, H. (2007) "KOBİ Niteliğindeki İşletmelerde Kurumsal Kaynak Planlaması Yazılımlarının Etkin Kullanılması İçin Kalite Fonksiyon Göçerimi Yaklaşımı”, Basılmamış Yüksek Lisans Tezi, Kırıkkale Üniversitesi, Fen Bilimleri Enstitüsü, Kirıkkale. 
Çolpan, C. (2003) "Müşteri Odaklılık Açısından Kalite Fonksiyonunun Yayılımı ve Üretici Bir isletmede Uygulama”, Basılmamış Yüksek Lisans Tezi, Osmangazi Üniversitesi Sosyal Bilimler Enstitüsü, Eskişehir.

Day, R.G. (1998) "Quality Function Deployment: Linking a Company with its Customers", ASQC Quality Press, Milwaukee.

Deros, B., Rahman, N., Rahman, M.N., Ismail, A.R. ve Said, A.H. (2009) "Application of Quality Function Deployment to Study Critical Service Quality Characteristics and Performance Measures", European Journal of Scientific Research, 33(3):398-410.

Emiroğlu, E. (2001) "Mamul Tasarımında Kalite Fonksiyon Açınımı Tekniği ve İnşaat Sektöründe Bir Uygulama Örneği”, Yayınlanmamış Yüksek Lisans Tezi, Gazi Üniversitesi Sosyal Bilimler Enstitüsü, Ankara.

Gonzalez, M., Quesada, G., Mueller, R.D. ve Mora-Monge, C. (2004) "QFD Strategy House: An Innovative Tool for Linking Marketing and Manufacturing Strategy", Marketing Intelligence and Planning, 22(3): 335-348.

Griffin, A. ve Hauser, J.R. (1993) "The Voice Of The Customer”, Marketing Science, 12(1):1-27.

Grover D. (2002) "Graphical Project Planning Techniques: An Overview of Gantt", PERT and CPM Charts Prepared for Groups in ECE480, http://www.soton.ac.uk/-jps7/ Aircraft $\% 20$ Design\%20Resources/project $\% 20$ management/ ganttv1.pdf

Guinta, L.R. ve Praizler, N.C. (1993) The QFD Book: The Team Approach to Solving Problems and Satisfying Customers Through Quality Function Deployment, New York, Amacom Books.

Güleş, H.K. ve Bülbül, H. (2004) Yenilikçilik-Işletmeler İ̧̧in Stratejik Rekabet Aracı, 1. Baskı, Ankara, Nobel Yayınları.

Han, B., Shaw K. Chen, Maling Ebrahimpour ve Manbir S. Sodhi (2001) "A Conceptual QFD Planning Model”, International Journal of Quality \& Reliability Management, 18(8): $796-812$.

Hauser, J.R. ve Clausing, D. (1988): "The House of Quality", Harvard Business Review, 66 (39: 63-73.

Juran, J.M. (1992) Quality Control Hand Book, Mc Graw-Hill, New York,

Kathiravana N., Devadasanb S.R., Bijumon M.T. ve Goyald S.K. (2008): "Total Quality Function Deployment in a Rubber Processing Company: A Sample Application Study", Production Planning \& Control, 19(1):53-66.

King, B. (1989) Better Designs in Half the Time: Implementing QFD Quality Function Deployment in America, 3. Bask1, Methuen, Massachusetts, GOAL/QPC.

Kuru, A. (1997) "Kalite Fonksiyonlarının Yayılımı ve Gelişimi”, Yayınlanmamış Yüksek Lisans Tezi, Uludağ Üniversitesi Sosyal Bilimler Enstitüsü, Bursa.

Lee Y.T., Wu W.W. ve Tzeng G.H. (2008) "An Effective Decision-Making Method Using a Combined QFD and ANP Approach", WSEAS Transactions On Business and Economics, 12(5):541-551.
Moran J.W. ve Nakul, V.S. (1991) Facilitating and Training in QFD, Methuen, Amacom Books,

Nicholas, J.M. (1998) Competitive Manufacturing Management, USA, McGraw-Hill.

Özdil, N. ve S. Dönmez (2002) “Örme Alanında Faaliyet Gösteren Bir Tekstil İsletmesinde Kalite Fonksiyon Göçeriminin Uygulanması", I. Ulusal Kalite Fonksiyon Göçerimi Sempozyumu, Dokuz Eylül Üniversitesi Yayınları, İzmir.

Özkan, Y., Demirel Ö. ve Zengin H. (2002) "Müşteri Sadakatinin Sağlanmasında QFD Metodolojisinin Kullanımı", I. Ulusal Kalite Fonksiyon Göçerimi Sempozyumu, Dokuz Eylül Üniversitesi Yayınları, İzmir.

Prasad K.G.D., Subbaiah K.V., Rao K.N. ve Sastry C.V.R.S. (2010) "Prioritization Of Customer Needs In House Of Quality Using Conjoint Analysis", International Journal for Quality Research 4(2):145-154.

Saaty, T.L. (1980) The Analytic Hierarchy Process, USA, McGraw-Hill International Book Company.

Savaş, H. (2002) "Kalite Fonksiyon Göçerimi ve Internet Kafeler Üzerine Bir Araştırma”, I. Ulusal Kalite Fonksiyon Göçerimi Sempozyumu, Dokuz Eylül Üniversitesi Yayınları, İzmir.

Savaş, H. ve Ay, M. (2005) "Üniversite Kütüphanesi Tasarımında Kalite Fonksiyon Göçerimi Uygulaması”, Dokuz Eylül Üniversitesi Sosyal Bilimler Enstitüsü Dergisi, 7(3):89-98.

Sharma J.R. ve Rawani M.A. (2010) "From Customers Requirements to Customers Satisfaction - Quality Function Deployment in Service Sector ", Int. J. Productivity and Quality Management, 5(4):428-439.

Sher, S.S. (2006) "The Application of Quality Function Deployment (QFD) in Product Development - The Case of Taiwan Hypermarket Building", Journal of American Academy of Business, 8(2):292-295.

Shillito, M.L. (1994) Advanced QFD: Linking Technology to Market and Company Needs, New York, USA, John Wiley $\&$ Sons, Inc.

Shores, A.R., (1990) A TQM Approach to Achieving Manufacturing Excellence, Milwaukee, Quality Press.

Slack, N. (2001) Operation Management Üçüncü basım, Essex, Pearson Education Limited.

Sofyalığlu, Ç. (2006) "Kalite Fonksiyon Göçerimi ve Gıda Sanayiinde Uygulanabilirliği: Kano Modeli İle Bütünleşik Bir Yaklaşım”. Celal Bayar Üniversitesi Sosyal Bilimler Enstitüsü, İşletme Anabilim Dalı, Basılmamış Doktora Tezi, Manisa.

TSE (1997): TS-EN-ISO 9000 ve TSE-ISO 9005, TSE 1994 3, DIN ISO 8402 Kalite Broşürleri.

Yalçın, D. (1999) "Gıda Üretiminde Hijyenik Riskler ve HACCP Uygulamaları", "Gıda Sanayinde Mikrobiyolojik Kalite Kontrolü Uygulamalı Eğitim Programı”, TÜBİTAK MAM GBTEA, Gebze, Kocaeli.

Yenginol, F. (2000) "Yeni Ürün Geliştirmede Müşteri İstek ve İhtiyaçlarını Teknik Karakteristiklere Dönüştürmeyi Sağlayan Bir Yöntem: Kalite Fonksiyon Göçerimi”, Yayınlanmamış Doktora Tezi, D.E.Ü, Sosyal Bilimler Enstitüsü, İşletme 
Bölümü, İzmir.

Yıldırım, H. (2002) "Kalite Fonksiyon Yayılımı ve Pazarlama Stratejisi Olarak Toplam Kalite Yönetiminde Uygulaması”, Yayınlanmamış Yüksek Lisans Tezi, Marmara Üniversitesi Sosyal Bilimler Enstitüsü, İzmir.
Zultner, R.E. (1993) “TQM for Technical Teams”, Communications of the ACM, 36(10): 79 - 91.

http://www.ciri.org.nz/downloads/Quality\%20Function\%20 Deployment.pdf (20.10.2009)

http://www.qfdi.org/whatiisiqfd/whatiisiqfd.htm (20.10.2009) 